\title{
Study of influence of the Ag addition for texturing process of Bi2212/Ag monofilament tapes by image analysis and $X$ ray diffraction
}

\section{Estudo da influência da adição de Ag no processo de texturização de fitas monofilamentares de Bi2212/Ag utilizando Análise de Imagem e Difração de Raios X}

Antônio Renato Bigansolli1 ${ }^{1}$ Tessie Gouvêa da Cruz¹, Durval Rodrigues Júnior²

\section{ABSTRACT}

The high Tc superconducting (HTS) materials are now applied in electric power systems. Cables, transformers and motors with superconducting tapes are now in test worldwide. However, HTS materials have intrinsic anisotropy that affects the values of their critical currents. Textured HTS samples present improved superconducting properties. This paper describes a study of the texturing process in monofilament tapes, using as HTS material the BSCCO system, i.e., 1G HTS tapes (Bi2212/Ag). The purpose of this paper is to present an alternative method using image analysis along with diffraction of X-rays technique as a resource in the characterization of the texturing process in superconducting ceramic Bi2212 tapes doped with Ag.

Keywords: Bi 2212/Ag tapes; SEM; Texturing; Image Analysis.

\section{RESUMO}

Materiais supercondutores de alta temperatura crítica - Tc (HTS) são atualmente aplicados em sistemas elétricos de potência. Cabos, transformadores e motores utilizando fitas supercondutoras estão atualmente em teste em todo o mundo. No entanto, os materiais HTS possuem uma anisotropia intrínseca que afeta os valores das suas correntes críticas. Amostras texturizadas de HTS apresentam propriedades supercondutoras melhoradas. O presente trabalho descreve um estudo sobre o processo de texturização em fitas monofilamentares, usando como material supercondutor o sistema BSCCO, ou seja, fitas supercondutoras de alta temperatura crítica (1G Bi2212/Ag). O objetivo deste trabalho é apresentar um método alternativo utilizando a análise de imagem juntamente com a técnica de Difração de Raios-X, como recurso na caracterização do processo de texturização em cerâmicas supercondutora de fitas Bi2212 dopadas com Ag.

Palavras-chave: Fitas de Bi2212/Ag; MEV; Texturização; Análise de imagem.

\footnotetext{
Universidade Federal Rural do Rio de Janeiro - Instituto de Tecnologia - Departamento de Engenharia Química - Seropédica (RJ) - Brazil. ${ }^{2}$ Escola de Engenharia de Lorena - Departamento de Materiais - Grupo de Supercondutividade - Lorena (SP) - Brazil. Correspondence author: Antonio Renato Bigansolli - UFRRJ - IT - Departamento de Engenharia Química - BR 465, Km7 - CEP 23.890-000 Seropédica (RJ) - Brazil

E-mail: bigansolli@ig.com.br

Received: 07/07/2015 Approved: 08/24/2015
} 


\section{INTRODUCTION}

Tapes of $\mathrm{Bi}_{2} \mathrm{Sr}_{2} \mathrm{CaCu}_{2} \mathrm{O}_{8+\mathrm{d}}$ doped with $\mathrm{Ag}(\mathrm{Ag} / \mathrm{Bi} 2212)$ have been revealed as promising materials for superconducting applications at low temperatures and high fields. The reaction and formation of phases are related to the ceramic densification and to the alignment of the grains, important for the improvement of the superconductor transport properties ${ }^{(1,2)}$. Slow cooling from the liquid to the solid state and long annealing heat treatment at temperatures below the melting temperature allow the conversion of the ceramic powder to $\mathrm{Bi}_{2} \mathrm{Sr}_{2} \mathrm{CaCu}_{2} \mathrm{O}_{8+\mathrm{d}}(\mathrm{Bi} 2212)^{(3)}$. The cooling process has great influence on the microstructure of PIT tapes (tapes produced by powder-in-tube (PIT) method). A large number of studies have been published relating the effects of cooling on the transport properties and microstructure of tapes processed $^{(4)}$. The cooling rate has great influence on the purity of the superconducting phase formed in the grain connectivity ${ }^{(5)}$ and texturing of the superconducting phase, important for the optimization of transport properties. The cooling step during the heat treatment is of vital importance for the formation of stoichiometric Bi2212 phase and textured superconducting phase both interests for the purposes of optimization of transport properties. Several quantitative analysis methods have been developed for study of morphologic and topology characteristics improving our understanding of structure parameters ${ }^{(6-8)}$. Both techniques and methods employed depend on the type of information sought when extracting and analyzing images. Alternative methods based on statistical analysis have been developed to characterize the features of composite materials by the combination of image analysis and statistical treatment. This paper describes a study of the texturing process in monofilament tapes, using as HTS material the BSCCO system, i.e., 1G HTS tapes $(\mathrm{Bi} 2212 / \mathrm{Ag})$. The purpose of this paper is to present an alternative method using image analysis along with diffraction of X-rays technique as a resource in the characterization of the texturing process in superconducting ceramic Bi2212 tapes doped with Ag.

\section{MATERIALS AND METHODS}

\section{Material Preparation}

The powder Bi2212 phase was doped with silver powder, giving rise to three different types of powders: $0 \mathrm{wt} \% \mathrm{Ag}, 10 \mathrm{wt} \% \mathrm{Ag}$ and $20 \mathrm{wt} \% \mathrm{Ag}$. In this method images obtained by SEM are used -shown in the Fig. 1(a) for $0 \mathrm{wt} \% \mathrm{Ag}$, Fig. 1(b) for $10 \mathrm{wt} \% \mathrm{Ag}$ and Fig. 1(c) for $20 \mathrm{wt} \% \mathrm{Ag}$. The result is a gray-scale image transformed in the segmented image, showing two phases: no interesting region (white) and grain boundary region (black). After segmentation it was applied the filter 'skeletonize' in order to make it possible to measure the features of texturing based in the orientation of pallets. It is possible to measure the features of interest for each of the specific objects. The measurable features regard size and shape. Parameters are according to Image) Software ${ }^{(9)}$. Using command 'particles analyze' it is calculated the angle between the primary axis and a line parallel to the $\mathrm{x}$-axis of the image. Based on this analysis a histogram was generated.

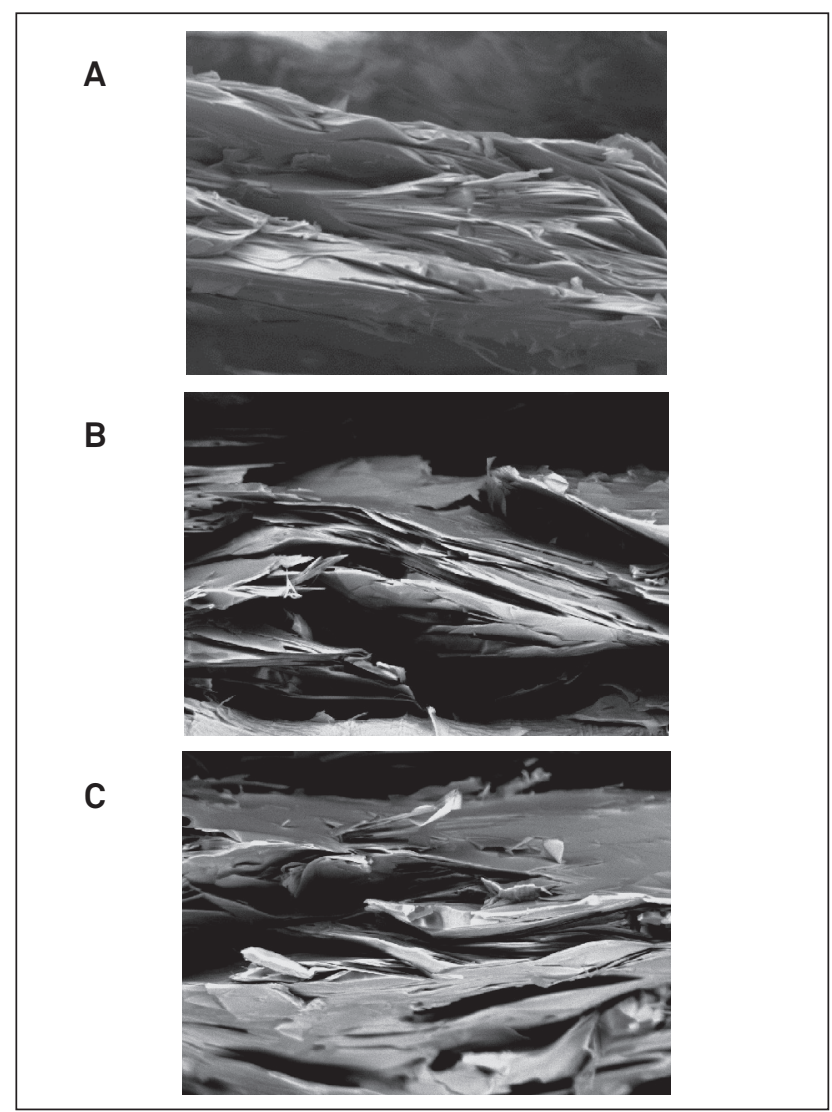

Figure 1: SEM micrograph sample of $\mathrm{Ag} / \mathrm{Bi2212}$ (A) 0 wt\%Ag;

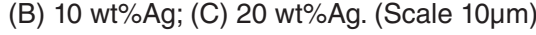

\section{Methods}

The methodology was developed following the routine (Fig.2): File $>$ Open $>$ Image $>$ Type $>8$-bit $>$ Process $>$ Filters $>$ Minimum $>$ Threshold $>$ Analyze $>$ Analyze Particles. At the end the software provided a table with a series of data obtained by SEM analysis. Among the generated data used for the analysis was that given in column Angle. This result allowed us to obtain a histogram angle versus frequency. If the material is textured the graph provides a values uniformity, but the more random the data is smaller the degree of texturing of the sample analyzed.

At the end of the above procedure the software generates a table with a data series that were calculated from direct analysis of the image obtained by SEM. The results used were only the ones on column Angle. The results were exported to spreadsheet calculations allowing to obtain a histogram angle vs. frequency.

\section{RESULTS AND DISCUSSION}

According to results shown in Figs. 3(a), 3(b) and 3(c), the angles values concentrate in the interval $140^{\circ}-180^{\circ} ; 10^{\circ}-180^{\circ}$ 
and $10^{\circ}-70^{\circ} ; 110^{\circ}-180^{\circ}$, respectively. These results show high alignment of pallets without doping sample, although all three show texturing. The effect of doping did not help to increase the texturing. These results are consistent with those observed in the SEM microstructures. Therefore the microstructure characterization using this technique proposed has shown versatility and good contribution for commonly used analysis.

Figs. $4 \mathrm{a}, 4 \mathrm{~b}$ and $4 \mathrm{c}$ shows de results obtained XRD the samples $0 \mathrm{wt} \% \mathrm{Ag}, 10 \mathrm{wt} \% \mathrm{Ag}$ and $20 \mathrm{wt} \% \mathrm{Ag}$, respectively.

There was a good texturing for samples treated in full cycle at a temperature of $890{ }^{\circ} \mathrm{C}$ without added Ag, lying

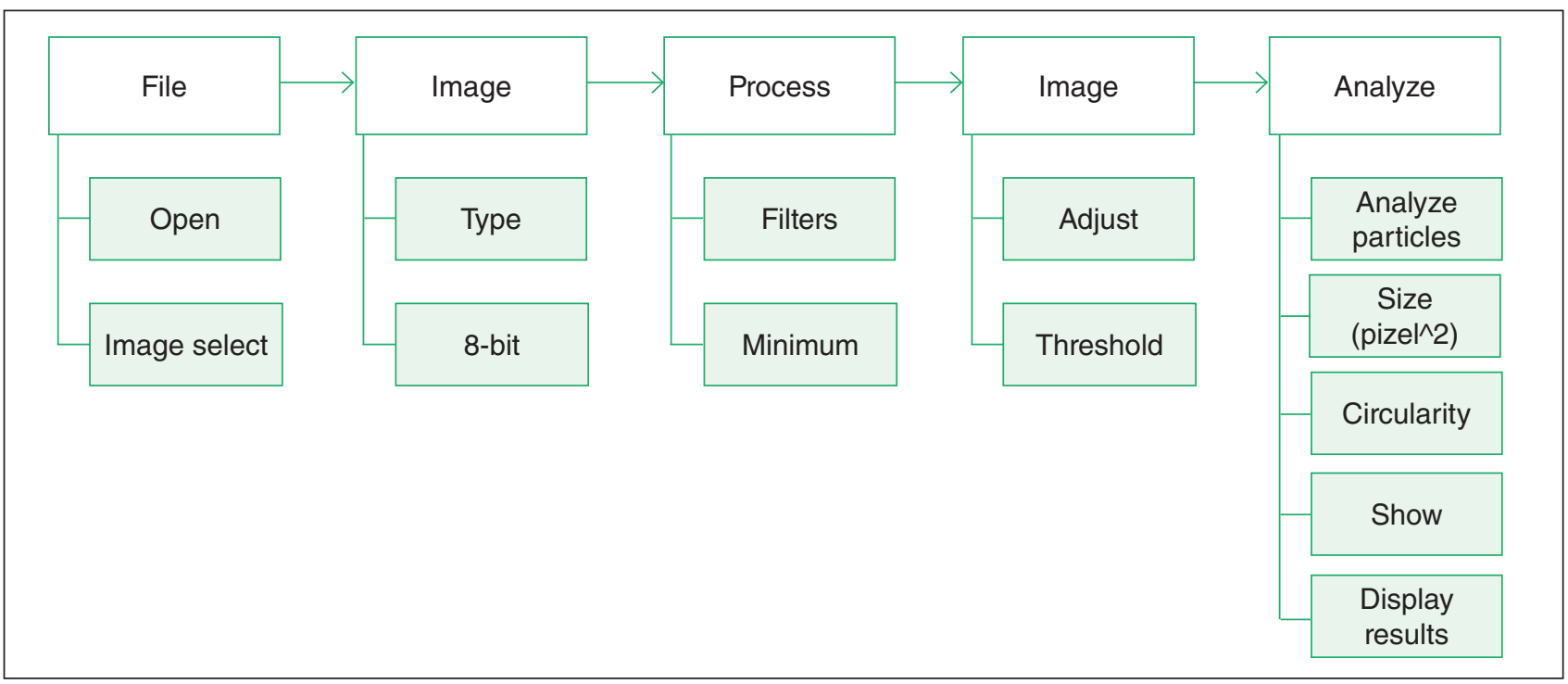

Figure 2: Routine using the program ImageJ.

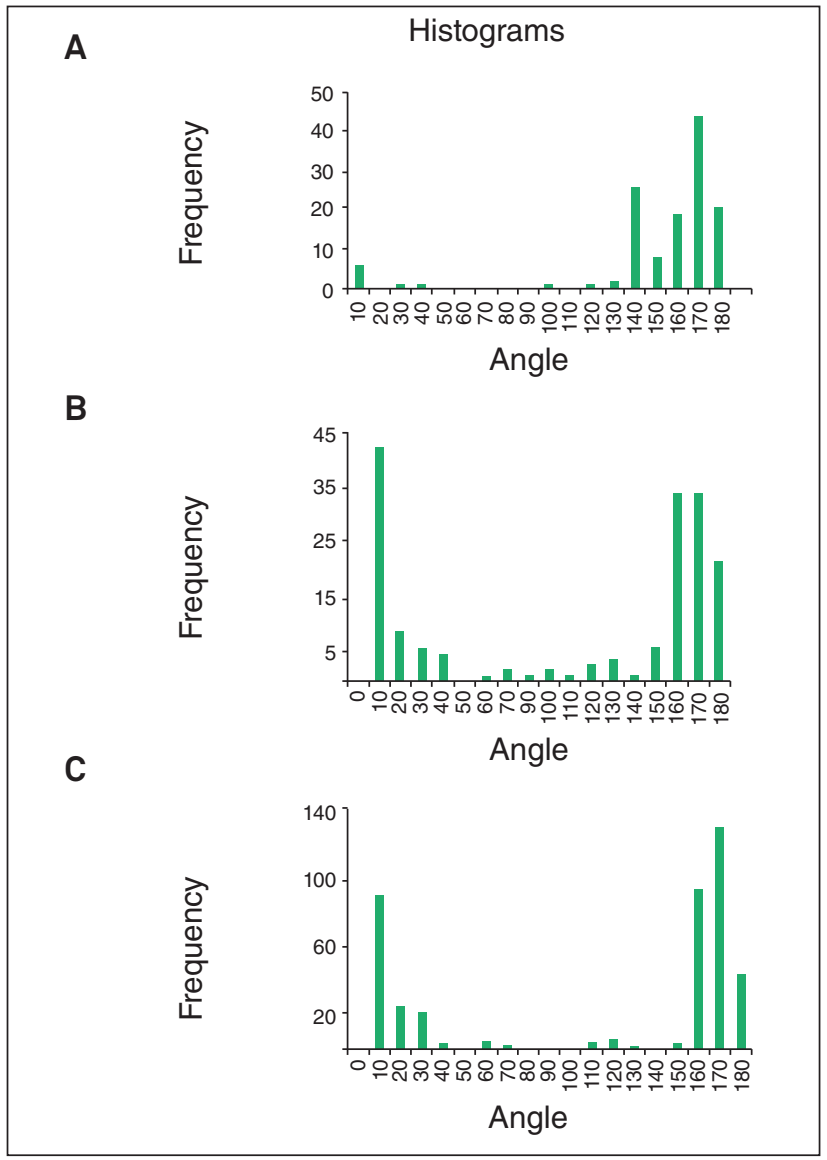

Figure 3: Distribution of angles sample of $\mathrm{Ag} / \mathrm{Bi2212}$ (A) $0 \mathrm{wt} \% \mathrm{Ag}$; (B) $10 w t \% A g ;(C) 20 w t \% A g$.

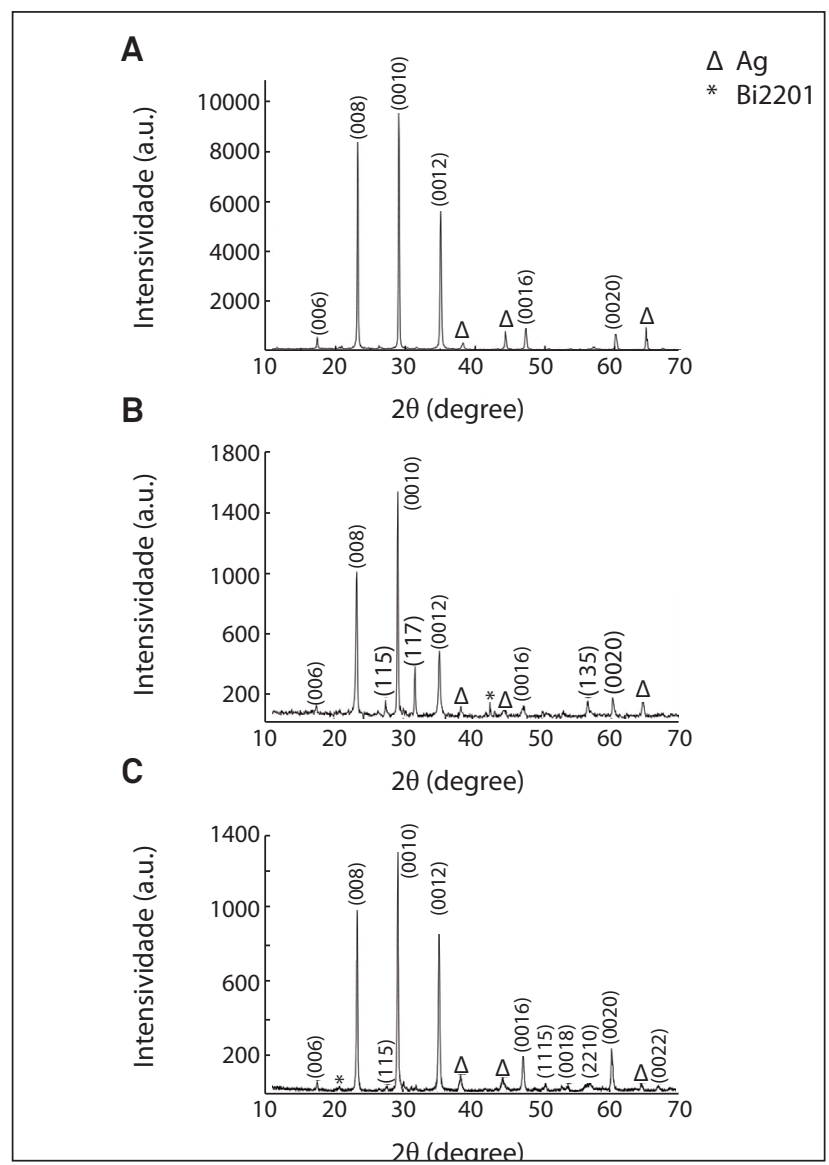

Figure 4: X-Ray diffraction of the heat treated tapes with maximum temperature of $890{ }^{\circ} \mathrm{C}$ (A) $0 \%$ wtAg, (B) $10 \%$ wtAg e (C) $20 \%$ wtAg 
peaks $(00 \ell)$ without the appearance of spurious phases, lying just Bi2212 phase present. The peaks associated silver (Ag) material are from the tape, as discussed earlier, is made of Ag.

In the samples containing 10 and $20 \mathrm{wt} \% \mathrm{Ag}$, for the same course of treatment, it was observed that degradation occurs Bi2212 phase with the appearance of the Bi2201 phase and no emergence of peaks belonging to the planes $(00 \ell)$ which shows a low texturing material compared to the sample without doping Ag.

When comparing the results of X-ray diffraction with the results obtained using the image analysis technique it is observed that the results are consistent. This gives evidence that the technique of image analysis (non-destructive technique) is effective and so complements the analysis of the process of texturing ceramic samples of Bi2212 superconducting tapes.

\section{CONCLUSION}

With the obtained results it can be concluded that for the selected heat treatment cycle, the addition of silver tends to degrade the texturing and also a Bi2212 phase, which found the presence of a Bi2201 phase at the expense of Bi2212 phase. These results show high alignment of pallets for both samples with or without doping, but without doping it has been observed higher degree of texturing. Therefore the microstructure characterization using this technique proposed has shown versatility and a good contribution for commonly used analysis.

\section{REFERENCES}

1. BIGANSOLLI, A. R.; CURSINO, E.; SANTOS, F. A.; RODRIGUES JR., D., Influence of the heat treatment profiles on the development of highly textured Ag/Bi2212 monofilamentary tapes. Journal of Physics. Conference Series (Online), United States of America, 43 (2006) 67-70.

2. RODRIGUES JR., D.; BIGANSOLLI, A. R., CURSINO, E.; PAPINI, P. S., Phase Formation and Evolution, Texturing and Current Transport in Ag/Bi2212 PIT Monofilamentary Tapes. IEEE Transactions on Applied Superconductivity (Print), United States, 15 (2005) 25462549.

3. LANG, T. H.; BUHL, D.; GAUCKLER, L. J., Physica C, 294 (1998) p. 7.

4. ANDERSEN, L.G.; POULSEN, H.F. et al., IEE Trans. Appl. Supercond., 9 (1999) 2758.

5. PARRELL, J. A. et al., IEEE Trans. Appl. Supercond., 5 (1995) 1275.

6. PRITSOS, C.; KONTONASAKIA, E.; CHATZISTAVROU, X.; PAPADOPOULOU, L.; PAPPAS, F.; P. KOIDIS, P. PARASKEVOPOULOS, K. M., Studying morphological characteristics of thermally treated bioactive glass ceramic using image analysis; Journal of the European Ceramic Society 25 (2005) 891-897.

7. MARCOMINI, R. F.; DE SOUZA, D. M. P. F., Microstructural characterization of ceramic materials using the image digital processing software Image J; Cerâmica 57 (2011) 100-105.

8. TAKANO, N.; ZAKO, M.; KUBO, F.; KIMURA, K., Microstructurebased stress analysis and evaluation for porous ceramics by homogenization method with digital image-based modeling; International Journal of Solids and Structures 40 (2003) 1225-1242.

9. http://rsb.info.nih.gov/ij. 